\title{
IDENTIFICATION OF STUDENTS' MISCONCEPTIONS IN FUNCTIONS TOPIC
}

\author{
Rilla Gina Gunawan ${ }^{1 *}$, Yuniza Maulana ${ }^{2}$, Rahmi Putri ${ }^{3}$ \\ ${ }^{1,2,3}$ Department of Mathematics Education, Faculty of Education and Teacher Training, Institut Agama \\ Islam Negeri Kerinci, Indonesia
}

*Corresponding author: rilla_rozika@yahoo.com

\begin{tabular}{|c|c|}
\hline Article Info & ABSTRACT \\
\hline Article history: & \multirow{9}{*}{$\begin{array}{l}\text { This study aimed to identify students' misconceptions on the topic } \\
\text { of function. The research used is qualitative research using } \\
\text { descriptive approach. The subjects of this study were class X MIA3 } \\
\text { selected by using purple sampling and snowball techniques. The } \\
\text { research instrument was a written test using diagnostic tes } \\
\text { techniques for misconceptions, interviews, and observations. The } \\
\text { qualitative data analysis techniques in this research are data } \\
\text { reduction, data presentation, and conclusion drawing/verification } \\
\text { Based on the research, there are } 4 \text { students who experience } \\
\text { misconceptions in class X MIA3 on the topic of the functions. Out } \\
\text { of } 6 \text { indicators of misconceptions, the reasons were caused by a lack } \\
\text { of student interest in learning, underestimating the concept of } \\
\text { functions so that they think learning the concept of functions is very } \\
\text { easy, embarrassed to ask questions when studying, and never repea } \\
\text { lessons at home so that students cannot answer questions given by } \\
\text { the teacher. }\end{array}$} \\
\hline Received: February 17, 2021 & \\
\hline Accepted: March 28, 2021 & \\
\hline Published: March 31, 2021 & \\
\hline Keywords: & \\
\hline Interviews & \\
\hline Students' misconceptions & \\
\hline Subject of functions & \\
\hline Test & \\
\hline
\end{tabular}

\section{IDENTIFIKASI MISKONSEPSI SISWA PADA TOPIK BAHASAN FUNGSI}

\section{Kata Kunci: \\ Wawancara \\ Miskonsepsi siswa \\ Pokok bahasan fungsi \\ Tes}

\begin{abstract}
ABSTRAK
Penelitian ini bertujuan untuk mengidentifikasi miskonsepsi siswa pada topik fungsi. Penelitian yang digunakan adalah penelitian kualitatif dengan menggunakan pendekatan deskriptif. Subyek penelitian ini adalah kelas X MIA3 yang dipilih dengan teknik purple sampling dan snowball. Instrumen penelitian ini adalah tes secara tertulis dengan menggunakan teknik tes diagnostik miskonsepsi, wawancara, dan observasi. Teknik analisis data kualitatif dalam penelitian ini adalah reduksi data (Reduction), Penyajian data (Display) dan Consclusion drawing/Verivication. Berdasarkan penelitian yang telah dilakukan, terdapat 4 orang siswa yang mengalami miskonsepsi dikelas X MIA3 pada functions topic terhadap 6 indikator miskonsepsi yang disebabkan oleh kurangnya minat belajar siswa, menyepelekan konsep functions sehingga menganggap mempelajari konsep functions itu sangat mudah, sikap malu bertanya pada saat belajar, dan tidak pernah mengulang pelajaran dirumah sehingga siswa tidak bisa dalam menjawab soal yang diberikan oleh guru.
\end{abstract}




\section{INTRODUCTION}

Mathematics has an important role in education because mathematics is considered as one of the main sciences which is the source of the development of other sciences [30]. Mathematics is also a science that is obtained by thinking (reasoning), so that it can train one's way of thinking and logic to prepare oneself to study other branches of science [21]. This means that mathematics is a subject that has important value in everyday life, because there are many problems in everyday life that require mathematics to solve them, such as measuring, building, and so on. But in fact, the problem was found that the students 'low ability to understand mathematics was found, this can be seen by the low score of students' understanding of mathematics as revealed in the TIMSS (Trends in Mathematics and Science Study) which placed Indonesia in the bottom rank. Considering that mathematics is important in education, the achievement of Indonesian students in mathematics in international competitions (which in question requires understanding mathematical concepts) is very low, it is very ironic. Therefore, mastery of mathematical concepts is one of the things that teachers must pay attention to. The indicators of the ability to understand mathematical concepts are: 1) define a concept verbally and in writing, 2) use models, diagrams, and symbols to present a concept, 3) identify the properties of a concept, 4) compare one concept to another [21]. Moreover, the low math ability can be seen from the National exam results report. We summarize the report on the results of the national exams in Jambi province on the topic of Functions, the results can be seen in Table 1.

Table 1. Report on The Results of The National Examination in Jambi Province and Kota Sungai Penuh

\begin{tabular}{clccc}
\hline No & \multicolumn{1}{c}{ Indicator } & $\begin{array}{c}\text { City } \\
(\mathbf{9 7 6})\end{array}$ & $\begin{array}{c}\text { Province } \\
(\mathbf{1 4 . 2 4 7})\end{array}$ & $\begin{array}{c}\text { National } \\
(\mathbf{9 7 3 . 2 5 3})\end{array}$ \\
\hline 1 & Determines the origin of a function. & 28,19 & 24,58 & 27,67 \\
2 & $\begin{array}{l}\text { Determines the function } f(x) \text { if the composition } \\
\text { 3 }\end{array}$ & 29,95 & 22,75 & 31,26 \\
& $\begin{array}{l}\text { Determines the value } f-1(c), c \text { of an integer } \\
\text { of a function } f(x)\end{array}$ & 33,97 & 26,36 & 32,95 \\
\hline
\end{tabular}

From the National exam results report above, there are three indicators tested, all of which are included in the Functions topic in mathematics learning. One of the causes of low math skills is the number of students who experience misconceptions [10].

Misconceptions are concepts that are incompatible with scientific understanding and are also incorrect hierarchical relationships of concepts. Students who experience misconceptions when working on practice questions will tend to experience misconceptions during exams, meaning that the misconceptions are repetitive. Therefore, misconceptions can cause difficulties for students in understanding the concepts of the next lesson [11]. Misconceptions in mathematics are a problem that must be considered important and must be considered carefully. If students experience misconceptions and are not handled immediately, they will also experience errors in concepts in the next lesson. So that it will result in continuous misunderstanding of the concept because students use the wrong concept as a basis for learning the next concept [16].

The observation used in this research is disguised observation [20]. Based on the results of observations made at SMA Negeri 3 Sungai Penuh on October 7, 2019, by giving a pre-research questionnaire to one of the class X mathematics teachers, it is known that students often underestimate the concept of function which causes students to experience errors in understanding other algebraic concepts. This characterizes that students experience a misconception. Not only observing, the researcher also conducted interviews with the math teacher, the teacher explained that misconceptions occurred due to the low 
ability and interest in student learning and low interaction between the teacher and students during the learning process, all of which occurred due to changes in learning methods from the 2006 curriculum to the curriculum. 213, so that students do not understand the methods used by the teacher when teaching, moreover, students also do not want to seek outside sources of knowledge (such as reading books) but only rely on knowledge that comes from the teacher. Concept understanding is the ability of students to master a number of concepts and be able to reuse them in other forms, be able to provide data interpretations and be able to apply concepts according to their cognitive structure [3],[5],[20]. The weak conceptual ability of students can be demonstrated in several ways, those are: 1) Students often experience errors in understanding a concept on the topic of function. 2) Students also often experience doubts in solving problems.

Based on previous research on research conducted by Kusumaningrum, et al, they used a written test accompanied by a CRI (Certainly Response Index) and interviews in identifying misconceptions. While in the research conducted by Sarlina, using observation data collection techniques, written tests and interviews [11]-[21]. The difference between previous research and this research is in the topics studied and data collection techniques. In this study, the topics studied focused on the topic functions with data collection techniques using tests, observations, interviews and documentation. In this regard, to find out more deeply about 'what are the misconceptions of Class X high school students on the subject of functions?' then the authors conducted research with the title "Identification of Student Misconceptions in Functions Topic".

Based on the problems presented, the main objectives of this study are: 1. To explain the types of misconceptions experienced by class X SMA Negeri 3 Sungai Penuh on the function material; 2. Causes of misconceptions of class X SMA Negeri 3 Sungai Penuh in Functions topic; 3. Suggest solutions to overcome misconceptions experienced by Siswin Functions topic.

\section{METHOD}

This research is qualitative research using a descriptive approach. Qualitative research is a study that describes and analyzes the phenomena, attitudes, beliefs, perceptions, activity, social events, and thoughts of a person individually or in groups. The descriptive approach describes and interprets data relating to facts, circumstances, variables, and phenomena that occur during the research [6]-[23]. In this study, the methods used were observation, tests ( 9 test questions were given here, all of which were related to problems in the topic of function), interviews and documentation [1],[4],[6],[13]. This study aims to describe and analyze in depth the types of misconceptions, causes of misconceptions, and solutions to overcome misconceptions of class X SMA Negeri 3 Sungai Penuh students. This research line is presented in Figure 1.

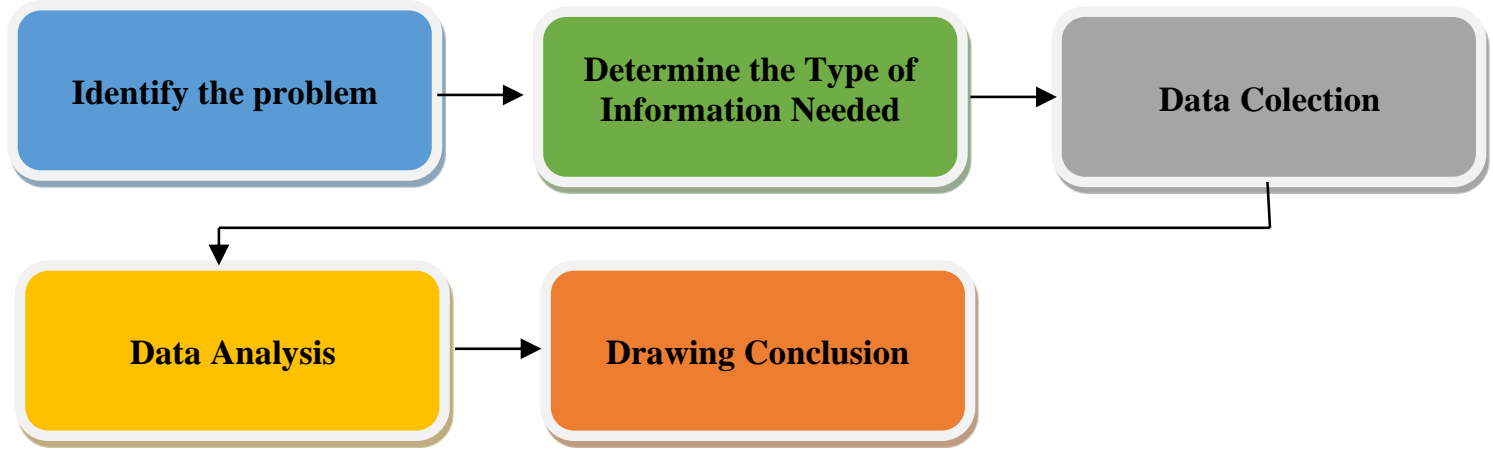

Figure 1. Research Procedure 
In this study, the research subjects were selected using purposive sampling and snowball sampling techniques. By assigning one or several people as research subjects and conducting interviews with them. They are then asked for directions, suggestions and instructions on who should be the research subject who according to them have the necessary knowledge, experience and information [24]- [29]. The types of data used in this study are primary data and secondary data. Primary data consists of test results and student interviews, while secondary data consists of books, journals and documentation. Sources of data in this study were students and teachers of SMA Negeri 3 Sungai Penuh.

In this study, the research object is presented in the form of informant research so that people can provide valid data and information as information and research data [8]. As for the research subjects in this study were the $\mathrm{X}$ grade mathematics teacher and the $\mathrm{X}$ grade students of SMA Negeri 3 Sungai Penuh.

The instrument in this study was in the form of essay test questions that had been arranged based on the question grid in accordance with the objectives of the study and had been validated by two validators. This question contains 9 items that concern the seven indicators of conceptual understanding.

Table 2. Misconception Test Question Grid

\begin{tabular}{|c|c|c|c|c|}
\hline Basic Competencies & & Indicator & $\begin{array}{c}\text { Conceptual Understanding } \\
\text { Indicator }\end{array}$ & $\begin{array}{c}\text { Number of } \\
\text { Items }\end{array}$ \\
\hline \multirow{4}{*}{$\begin{array}{l}\text { 3.5 Describe and define } \\
\text { functions } \\
\text { (especially linear } \\
\text { functions, quadratic } \\
\text { functions, rational } \\
\text { functions) in a } \\
\text { formal manner that } \\
\text { includes notation, } \\
\text { area of origin, area } \\
\text { of results, and } \\
\text { symbolic } \\
\text { expressions as well } \\
\text { as graphical } \\
\text { sketches }\end{array}$} & 3.5 .1 & \begin{tabular}{lr}
\multicolumn{1}{c}{ Students } & can \\
explain a & graph \\
and & linear \\
functions. &
\end{tabular} & $\begin{array}{l}\text { 1. Students are able to classify an } \\
\text { object according to certain } \\
\text { properties (according to the } \\
\text { concept). } \\
\text { 2. Students are able to present } \\
\text { concepts in representative form } \\
\text { or mathematical symbols. [13] }\end{array}$ & 1 \\
\hline & 3.5 .2 & $\begin{array}{l}\text { The student can } \\
\text { determine the } \\
\text { origin and result } \\
\text { area } \\
\text { (symbolically) of } \\
\text { the quadratic } \\
\text { function. }\end{array}$ & $\begin{array}{l}\text { 1. Students are able to restate an } \\
\text { object. } \\
\text { 2. Students are able to classify an } \\
\text { object according to certain } \\
\text { properties (according to the } \\
\text { concept). }\end{array}$ & 2 \\
\hline & 3.5 .3 & $\begin{array}{l}\text { Students can } \\
\text { determine the } \\
\text { area of origin, } \\
\text { area of friends, } \\
\text { and area of results } \\
\text { by using the } \\
\text { arrow diagram. }\end{array}$ & $\begin{array}{l}\text { 1. Students are able to restate an } \\
\text { object. } \\
\text { 2. Students are able to classify an } \\
\text { object according to certain } \\
\text { properties (according to the } \\
\text { concept). } \\
\text { 3. Students are able to present } \\
\text { concepts in representative form or } \\
\text { mathematical symbols. }\end{array}$ & 3 \\
\hline & 3.5 . & $\begin{array}{l}\text { Students are able to } \\
\text { explain and } \\
\text { determine the } \\
\text { function of } \\
\text { relations by using } \\
\text { function notation. }\end{array}$ & $\begin{array}{l}\text { 1. Students are able to restate an } \\
\text { object. } \\
\text { 2. Students are able to classify an } \\
\text { object according to certain } \\
\text { properties (according to the } \\
\text { concept). } \\
\text { 3. Students are able to determine } \\
\text { which one is the examples and } \\
\text { the non-examples of a concept. } \\
\text { 4. Students are able to develop the } \\
\text { necessary or sufficient conditions } \\
\text { of a concept. }\end{array}$ & 4 \\
\hline
\end{tabular}




\begin{tabular}{|c|c|c|c|}
\hline & $\begin{array}{l}\text { 3.5.5 Students are able to } \\
\text { determine } \\
\text { functions and } \\
\text { explain the } \\
\text { properties of a } \\
\text { function. }\end{array}$ & $\begin{array}{l}\text { 1. Students are able to classify an } \\
\text { object according to certain } \\
\text { properties (according to the } \\
\text { concept) } \\
\text { 2. Students are able to distinguish } \\
\text { examples and non-examples of a } \\
\text { concept. }\end{array}$ & 5 \\
\hline \multirow{2}{*}{$\begin{array}{lr}3.6 & \text { Describe } \\
\text { composition } \\
\text { operations an } \\
\text { functions and } \\
\text { inverse operations } \\
\text { on } \\
\text { functions and their } \\
\text { properties and } \\
\text { determine } \\
\text { existence. }\end{array}$} & $\begin{array}{l}\text { 3.6.1 Students are able to } \\
\text { determine the } \\
\text { function in the } \\
\text { composition } \\
\text { function } \\
\text { operation. }\end{array}$ & $\begin{array}{l}\text { 1. Students are able to use, utilize } \\
\text { and select certain procedures or } \\
\text { operations. }\end{array}$ & 6 \\
\hline & $\begin{array}{l}\text { 3.6.3 Students are able to } \\
\text { determine the } \\
\text { inverse of the } \\
\text { inverse operation. }\end{array}$ & $\begin{array}{l}\text { 1. Students are able to use, utilize } \\
\text { and select certain procedures or } \\
\text { operations. }\end{array}$ & 7 \\
\hline \multirow[t]{2}{*}{$\begin{array}{l}\text { 4.6 Solving problems } \\
\text { related to } \\
\text { composition } \\
\text { operations and } \\
\text { inverse operations } \\
\text { of a function. }\end{array}$} & $\begin{array}{l}\text { 4.6.1 Students are able to } \\
\text { solve problems } \\
\text { related to the } \\
\text { composition } \\
\text { operation of a } \\
\text { function. }\end{array}$ & $\begin{array}{l}\text { 1. Students are able to present } \\
\text { concepts in representative form } \\
\text { or mathematical symbols. } \\
\text { 2. Students are able to use, utilize } \\
\text { and select certain procedures or } \\
\text { operations. } \\
\text { 3. Students are able to develop } \\
\text { concepts or algorithms in } \\
\text { problem solving. }\end{array}$ & 8 \\
\hline & $\begin{array}{l}\text { 4.6.2 Students can solve } \\
\text { problems related } \\
\text { to the inverse } \\
\text { operation of a } \\
\text { function. }\end{array}$ & $\begin{array}{l}\text { 1. Students are able to present } \\
\text { concepts in representative form } \\
\text { or mathematical symbols. } \\
\text { 2. Students are able to use, utilize } \\
\text { and select certain procedures or } \\
\text { operations. } \\
\text { 3. Students are able to develop } \\
\text { concepts or algorithms in } \\
\text { problem solving. }\end{array}$ & 9 \\
\hline
\end{tabular}

Furthermore, the second research instrument is the interview. Interviews were conducted to verify the answers that had been written by students to the test questions given, as well as to obtain information about the causes of errors in answering the test questions that were given. The interview that was conducted was semistructured, because the interview technique was carried out in the form of semistructure, an interview guide was needed. The interview guidelines were prepared based on the interview grid and were validated by two validators [7]. The last research instrument is observation. Observations made in the form of direct observation during tests and interviews. Observations were controlled with an observation sheet [14].

The data analysis methods used are 1. Data reduction, data analysis is used to summarize and select things that are included in the focus of this research based on the results of observations and interviews, 2. Data presentation (Display), data presentation techniques are carried out in the form of a brief description or narrative text in accordance with the observed aspects, 3. Drawing a conclusion/verification is drawing a creative conclusion so that it can answer the problem formulation [17] 


\section{RESULTS AND DISCUSSION}

From the results of the analysis of students' answers on the topic of function, all students of class X MIA 3 experienced misconceptions. But as a sample to be analyzed further, the researcher took 4 students, the four students were selected because they experienced the highest misconceptions. The research results obtained by researchers are shown in Table 3.

Table 3. Research Results on Class X Students of SMA Negeri 3 Sungai Penuh

\begin{tabular}{clcc}
\hline No & \multicolumn{1}{c}{ Misconception Indicator } & Respondent Code & $\begin{array}{c}\text { Number } \\
\text { of Items }\end{array}$ \\
\hline 1 & $\begin{array}{l}\text { Inaccurate understanding of a concept does not follow } \\
\text { scientific concepts discovered by scientists (theory). }\end{array}$ & DM, AZP, TP, DL & $4,6,8$ \\
2 & $\begin{array}{l}\text { Unable to classify objects from the concept correctly. } \\
\text { Students cannot correctly differentiate or classify which are } \\
\text { examples and non-examples of the concept. }\end{array}$ & DM & 4 \\
5 & $\begin{array}{l}\text { Cannot present the concept in other simpler forms or in the } \\
\text { form of sibol-symbols in mathematics. }\end{array}$ & AZP & 4 \\
6 & $\begin{array}{l}\text { Students do not know the correct coverage requirements for } \\
\text { a concept. }\end{array}$ & DP & 4 \\
7 & $\begin{array}{l}\text { Using the wrong concept } \\
\text { Not being able to develop the concept correctly and not using } \\
\text { the real concept instead using the wrong concept }\end{array}$ & TP & 6 \\
\hline
\end{tabular}

Based on the results of interviews of researchers with students who experience concept errors and mathematics teachers who are one of the sources of misconceptions, it is known that the lack of student interest in learning makes students lazy to dig deeper into concepts, this is indicated by students who are not serious in learning, students who perceive concepts The function is very easy, students who don't ask questions when they don't understand, and students who never repeat their studies at home, so students can't answer questions given by the teacher. The solution that researchers can give to students who experience misconceptions is to add interest in learning, be more diligent in learning, not lazy, ask questions if they don't understand, dare to express opinions, and don't forget to study at home.

The types of misconceptions experienced by Class X MIA 3 students are: a. Wrong in classifying objects from the concept. In the indicator of misconceptions about errors in classifying objects from the concept [2] there is one student (DM) who experienced a misconception. The misconceptions experienced by students are in question number 4 . The misconception in question number (4) is because DM did not know which one included in the properties of function (A) and function (B), one of the two has natural number and number which is functions of $f(x)=2 x$. b. Cannot distinguish which is an example of a concept and which is not an example of a concept properly. In this indicator, there is one student who experiences misconceptions. Concept errors experienced by students are in question number (4), DP students cannot distinguish between relations and functions, this is because DP does not know the concept of relations and the concept of function so that DP has difficulty in classifying and determining which one is examples and non examples of concepts. c. Cannot present the concept in other, simpler forms or in the form of symbols in mathematics. There is one student who has a misconception on this indicator. The student is an AMP. The misconception made by AMP is in question number 8 . The misconception in question number (8) is that AMP made a mistake in presenting the concept in the form of mathematical symbols regarding basic salary, family allowances, and health benefits, causing further errors in determining the formula based on mathematical symbols. d. Do not know the necessary terms and conditions of a concept 
correctly. In this misconception indicator, there is 1 student (DP) who experiences a misconception. The misconception experienced by the DP is in question number (4) point $\mathrm{c}$, here the DP student cannot develop the necessary and sufficient conditions of a concept of a relation. e. Using the wrong concept in applying the concept to certain procedures or operations. In this indicator, there are two students who experience misconceptions, TP and AMP. The mistake made by the TP in question number (6) was that the TP could not use, utilize, and choose the appropriate procedure or operation to work on story questions about the amount of health benefits and employee salaries, f. Cannot develop a concept correctly and do not use the actual concept but use another wrong concept. In this indicator, there is one student who experiences misconceptions. Students who experience misconceptions are AMPs. The misconception made by AMP is problem number (9), where AMP cannot change the story problem into the form of mathematical symbols to solve concepts or problem solving algorithms.

Based on the results of interviews with students and mathematics teachers, the causes of students experiencing misconceptions are as follows: a. DM has never studied seriously during the learning process. b. The misconceptions experienced by DP students occur because DP has never studied seriously during the learning process and is always lazy studying at home, c. The cause of the misconceptions of AMP students is that AMP is not serious in learning, AMP also tends to conclude a concept by itself without confirming it to the teacher or other learning resources, $\mathrm{d}$. The cause of the misconception of DP students is because DP has never studied seriously during the learning process, e. Misconceptions for TP students because TP students are not serious about learning during the learning process and also never study at home, f. AMP students' misconceptions occurred because AMP never studied seriously during the learning process and also AMP always underestimated learning.

Based on the causes of misconceptions experienced by students of class X MIA3 SMA Negeri 3 Sungai Penuh, researchers provide solutions to students based on the causes of the misconceptions. The solutions for the causes of misconceptions based on each indicator of concept understanding are: a. Researchers provide solutions to student so that he/she is always enthusiastic in learning, no longer underestimate function lessons. b. Researchers provide solutions to be more enthusiastic and serious in the learning process, and researchers also tell student about the importance of studying at home. c. The solution given by the researchers is to increase interest in learning again and not hesitate to express opinions or ask questions when the teacher explains the lesson in front of the class, $d$. The solution given by researchers to student is that student must try to increase her/his interest and seriousness in learning. e. Student must always be serious, serious, and passionate about learning. f. Student must maintain enthusiasm in learning, always apply selfdiscipline in learning, always listen to the teacher when explaining lessons in front of the class, and also should not underestimate a lesson.

\section{CONCLUSION}

From this study, it is known that the cause of students experiencing misconceptions is due to the lack of student interest in learning which is showed by students who were not serious in learning, students who underestimated learning functions, students who were embarrassed to ask the teacher, and students who never repeat learning at home. The solution to overcome this is by carrying out learning activities that can increase interest in learning, so that students are more diligent in learning, not lazy, dare to ask questions and express opinions, as well as enthusiasm for studying at home. With this research, teachers and students get information related to reasons and solutions to reduce and overcome 
student misconceptions. Because in this study, researchers explained the types of misconceptions experienced by students and the causes of misconceptions. For the next research, it is better to research about misconception in on other topics

\section{REFERENCES}

[1] Andriani, T., Suastika, I. K., \& Sesanti, N. R. (2017). Analisis kesalahan konsep matematika siswa dalam menyelesaikan soal trigonometri kelas X TKJ SMKN 1 Gempol tahun pelajaran 2016/2017. Pi: Mathematics Education Journal, 1(1), 3439.

[2] Anggara, B. (2020). Pengembangan Soal Higher Order Thinking Skills Sebagai Tes Diagnostik Miskonsepsi Matematis Siswa SMA. Algoritma: Journal of Mathematics Education, 2(2).

[3] Fatqurhohman. (2009). Representasi Matematis Dalam Membangun Pemahaman Konsep Pecahan. Jurnal Math Educator Nusantara, 02(01), 43-54.

[4] Febriansyah, A., \& Herviani, V. (2016). Tinjauan Atas Proses Penyusunan Laporan Keuangan pada Young Enterpreneur Academy Indonesia Bandung. Jurnal Riset Akuntansi, VIII(2), 9-17.

[5] Febriyanto, B., Haryanti, Y. D., \& Komalasari, O. (2018). Peningkatan Pemahaman Konsep Matematis Melalui Penggunaan Media Knatong Bergambar pada Materi Perkalian Bilangan di Kelas II Sekolah Dasar. Jurnal Cakrawala Pendas, 4(2), 113.

[6] Hadi, A., \& Haryono. (2005). Metodologi Penelitian Pendidikan. bandung: CV Pustaka Setia.

[7] Herutomo, R. A., \& Saputro, T. E. M. (2014). Analisis kesalahan dan miskonsepsi siswa kelas VIII pada materi aljabar. Edusentris, 1(2), 134-145.

[8] Iskandar. (2009). Metodologi Penelitian Pendidikan dan Sosial. Jakarta: Agung Persada Press.

[9] Jannah Ulfatul A (2015). "Analisis Miskonsepsi Siswa dalam Pembelajaran Pecahan Aljabar pada Siswa SMP Kelas VIII”. Simki-Techsain Vol. 02 No. 03 Tahun 2018 ISSN : 2599-3011

[10] Kebudayaan, K. P. dan. (2020). From : To : Attachments : Laporan Hasil Ujian Nasional.

[11] Kusumaningrum, D., Napitupulu, B., \& Tyas, D. K. F. N. (2017). Analisis Miskonsepsi Siswa di Kleas XI SMA Negeri 1 Jayapura pada Materi Fungsi Komposisi. Jurnal Ilmiah Matematika Dan Pembelajarannya, 2(1), 14-21.

[12] Mahmud. (2010). Psikologi Pendidikan. Bandung: CV Pustaka Setia.

[13] Malikha, Z., \& Amir, M. F. (2018). Analisis Miskonsepsi Siswa Kleas V-B MIN Buduran Sidoarjo pada Materi Pecahan Ditinjau dari Kemampuan Matematika. Mathematics Education Journal, 1(2), 75-81.

[14] Mentari, L., Suardana, I. N., \& Subagia, I. W. (2017). Analisis Miskonsepsi Siswa SMA pada pembelajaran Kimia untuk materi larutan penyangga. Jurnal Pendidikan Kimia Undiksha, 1(1).

[15] Nafi, A. Y. (2017). Pemahaman Siswa SMP Terhadap Konsep Persamaan Linear Satu Variabel ( PLSV ) Ditinjau dari Perbedaan Jenis Kelamin. Jurnal Ma t Ema $\begin{array}{llllllllll}\text { Tika } & K & r & \text { Ea Tif } & \text {-Ino } & v & a & \text { Tif, } & 8(2), & 119-125 .\end{array}$ https://doi.org/1015294/kreano.v8i2.10259

[16] NUR AINI, S. I. T. I. (2020). Analisis Miskonsepsi Matematika Siswa Pada Materi Operasi Hitung Pecahan Desimal Kelas V di Sekolah Dasar. Jurnal Penelitian Pendidikan Guru Sekolah Dasar, 8(2). 
[17] Nurkamilah, P., \& Afriansyah, E. A. (2021). Analisis Miskonsepsi Siswa pada Bilangan Berpangkat. Mosharafa: Jurnal Pendidikan Matematika, 10(1), 49-60.

[18] Rigdom, V. P. (2007). Kalkulus Edisi ke Sembilan Jilid 1. Jakarta: Erlangga.

[19] Roslina, \& Mahdi, M. (2015). Kemampuan Menguasai Materi Sistem Persamaan Linear Tiga Variabel Siswa SMA Negeri 14 Iskandar Muda Banda Aceh. Jurnal Ilmiah "Integritas, 1(2), 43-52.

[20] Sari, E. F. P. (2017). Pengaruh Kemampuan Pemahaman Konsep Matematika Mahasiswa Melalui Metode Pembelajaran Learning Starts With A Question. Jurnal "Mosharafa," 6(1), 25-34.

[21] Sarlina. (2015). Miskonsepsi siswa terhadap pemahaman konsep matematika pada pokok bahasan persamaan kuadrat siswa kelas x 5 sma negeri 11 makassar. MaPan : Jurnal Matematika Dan Pembelajaran, 3(2), 194-209.

[22] Simanjuntak, M. (2018). Meningkatkan Kemampuan Pemahaman Konsep Siswa Dalam Materi Segitiga Melalu Model Pembelajaran Kooperatif Tipe Think-PairShare (TPS) Berbantuan Autograph di Kelas VII SMP Santo Antonius Jakarta. MES (Journal of Mathematics Education and Science), 3(2), 167-174.

[23] Subana, \& Sudrajat. (2005). Dasar-dasar Penelitian Ilmiah. Bandung: CV Pustaka Setia.

[24] Sugiyono. (2009). metode penelitian kuantitatif kualitatif dan $R \& D$ (7th ed.). Bandung: Alfabeta.

[25] Sunhaji. (2014). Konsep Manajemen Kelas dan Implikasinya dalam Pembelajaran. Jurnal Kependidikan, II(2), 30-46. https://doi.org/10.24090/jk.v2i2.551

[26] Supriadie, D. (2012). Komunikasi Pembelajaran. Bandung: PT Remaja Rosdakarya.

[27] Syafitri, \& Lili. (2020). Analisis Kesalahan Siswa Dalam Menyesaikan Soal Operasi Hitung Aljabar Ditinjau dari Objek Matematika pada Siswa Kleas VII SMP Kencana Sastra T.P 2019/2020. Muhammadiyah Sumatera Utara.

[28] Thersesia, \& Seputro, T. (1992). Pengantar Dasar Matematika Logika dan Teori Himpunan. jakarta: erlangga.

[29] Wardani, E. P., Mardiyana, M., \& Subanti, S. (2016). Analisis miskonsepsi siswa pada materi pokok lingkaran ditinjau dari kesiapan belajar dan gaya berpikir siswa kelas XI IPA SMA N 3 Surakarta tahun ajaran 2013/2014. Jurnal Pembelajaran Matematika, 4(3).

[30] Widyawati, S. (2016). Pengaruh Gaya Belajar Terhadap Prestasi Belajar Mahasiswa Program Studi Pendidikan Matematika (IAIM NU) Metro. Al-Jabar: Jurnal Pendidikan Matematika, 7(1), 107-114. 